\title{
Study of agglomeration in fluidized bed gasification of biomass using CPFD simulations
}

\author{
Nora C I S Furuvik Rajan Jaiswal Rajan K Thapa Britt M E Moldestad
}

\begin{abstract}
Department of Process, Energy and Environmental Technology, University of South-Eastern Norway, Norway, \{nora.c.i.furuvik rajan.k.thapa, britt.moldestad\}@usn.no Rajanjaiswal357@outlook.com
\end{abstract}

\begin{abstract}
Fluidized beds have been widely applied for the gasification of biomass. However, at high temperatures ash melting and subsequently bed agglomeration may occur. When biomass is used for thermal conversion processes, inorganic alkali components present in the biomass fuels can be responsible for major problems. Understanding the ash melting and agglomeration in various gasification temperatures is crucial to optimize the design and operation conditions of a fluidized bed gasifier. This study focuses on the ash melting and the agglomeration process in a bubbling fluidized bed biomass gasification reactor. Using standard techniques, ashmelting analyses were performed to determine the initial agglomeration temperature in laboratory prepared ash samples from woodchips from Austria. Computational Particle Fluid Dynamic (CPFD) simulations were carried out using the commercial CPFD software package Barracuda Virtual Reactor (VR). The results show that the fluid dynamics gives important indications of unwanted agglomeration processes in a biomass gasification in a bubbling fluidized bed.
\end{abstract}

Keywords: bubbling fluidized bed, biomass gasification, agglomeration, CPFD simulations

\section{Introduction}

Climate changes are perhaps the biggest and most challenging environmental problems the world faces today. Greenhouse gas emissions from burning of fossil fuels for heat and power generation are major contributors to the earth's global warming. Over the last decades, it has been a growing attention to the use of renewable energy as an effective tool to fight the climate changes. On global basis, renewable energy were estimated to account for $14.1 \%$ of the total $573 \mathrm{EJ}$ of primary energy supply in 2014, of which the largest energy contributor was biomass (10.3\%) (World Bioenergy Association, 2017).

Fluidized bed gasification (FBG) is an important route for conversion of biomass into useful gaseous products, including syngas that can be further utilized into biofuels. Fluidized bed gasifiers offer distinct advantages over other conversion technologies, especially regarding to their uniform temperatures and excellent heat transfers. (Basu, 2013) However, because of the special ash-forming constituents of biomass fuels, biomass ash has shown to be particularly problematic in high temperature FBG processes (Wang et al., 2008). Generally, these problems are associated with the ash melting and following agglomeration of bed material (Van der Drift, 1999). Bed agglomeration is a result of interaction between the bed material and molten biomass ash with high content of alkali metals. When biomass is used for thermal conversion, alkali species from the fuel can react readily with silica $(\mathrm{Si})$ from the bed material. As a consequence, the particles become coated with an adhesive layer that glue the particles together forming larger agglomerates. (Bartles et al., 2008) Bed agglomeration leads to poor fluidization conditions, and in the most severe cases it causes defluidization and subsequently total shutdown of the gasification process. Fundamental understanding of the ash behavior in thermal conversion of biomass, is necessary to improve the operational conditions in FBG (Khadilkar, 2018).

The objective of this work is to (a) study the melting behavior of woody biomass ash in correlation to standard ash melting tests (b) use a previous validated CPFD model to simulate agglomeration in a bubbling fluidized bed gasifier.

The ash-melting analyses are performed using a Leco Ash Fusion Determinator (AF700). In this test, the temperature at which the ash starts to melt is determined, giving a good indication of the temperature at which agglomerates can be formed. Laboratory prepared ash from woodchips from Austria are used for the ash melting analyses. The CPFD model is developed to get a better understanding of the problem with agglomeration phenomenon in a bubbling fluidized bed biomass gasification reactor. The connection between the ash melting behavior, operating temperatures and bed agglomeration in a FBG is investigated. The simulations are carried out using the commercial CPFD software package Barracuda VR. 


\section{Theory}

\subsection{Bed agglomeration}

In the literature, there is good agreement that alkali metals are the main components causing problems with bed agglomeration in FBG of biomass. (Bartles et al., 2008) The agglomeration process happens in two ways, either as melt-induced agglomeration or as coatinginduced agglomeration. The melt-induced mechanism is direct adhesion of the bed particles because of alkali compounds from the molten ash acting as a glue that forms hard bridges between the particles. The coatinginduced mechanism happens due to chemical reactions, between the bed material and the molten ash components, causing formation of a sticky uniform coating layer on the surface of the bed particles. (Visser et al., 2008) Bed agglomeration is in most cases a result of the inorganic alkali ash components combining with $\mathrm{Si}$, either from the bed material or from the ash itself, to form low-melting silicates (eutectics) that coat the bed particles. These eutectics are characterized by a lower melting point than the individual components. If the alkali concentrations are too high, the coating melts and adheres the particles together. As a consequence of repeated collisions between these sticky ash-coated particles, the particles eventually grow towards larger agglomerates. (Badhoilya, 2018) The phenomenon is shown in Figure 1, an illustration based on (Moradian).

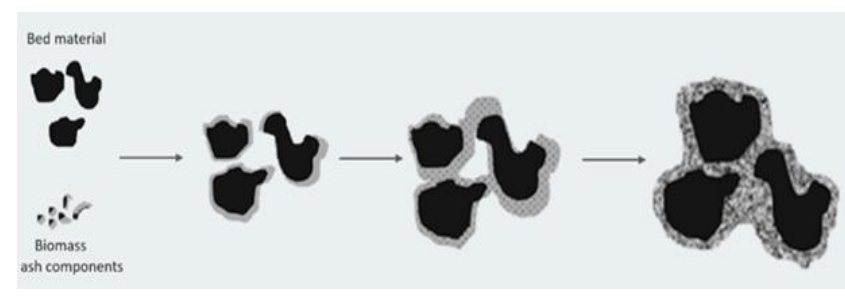

Figure 1. Agglomeration process.

Ash melting and following bed agglomeration is a key concern in fluidized bed biomass gasification reactors. The problems are mainly coupled to the high temperature chemistry of ash, i.e. its melting at different gasification temperatures. Proper fluidization of the particles needs to be maintained in order to stabilize the operational conditions of the fluidized bed (Badholiya 2018). As the agglomerated particles are of greatly irregular shape, size and structure, they will interfere with the fluid dynamics in the bed. In Figure 2 agglomerates from bubbling fluidized bed gasification of biomass is pictured.

In FBG the particle movement is one of the most important factors due to the corresponding transfer of energy. Under normal conditions, this energy transfer is so effective that the temperature difference across the cross section of the bed is kept approximately equal to zero. When agglomerates are present in the bed, the bed mixing becomes more ineffective due to obstructed particle movement. If this agglomeration process comes out of control, it can lead to severe agglomerate formation and subsequently shutdown of the gasification process. (Bartles et al., 2008, Badhoilya 2018) The obstruction in the particle movement can result in local temperature deviations that in turn creates de-fluidized volumes in the bed. De-fluidization is described as a total collapse of the fluidized bed leading to rapidly decreasing pressure drop and substantial temperature changes. (Van der Drift, 1999)

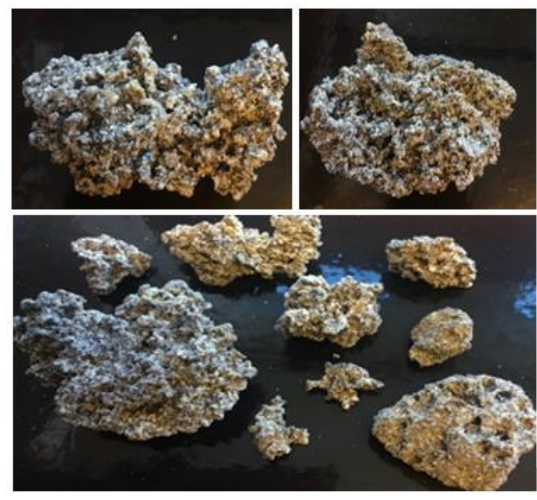

Figure 2. Agglomerates from silica sand particles.

\subsection{Ash melting}

Biomass is greatly varying in its physical properties and chemical composition, and the ash melting behavior is greatly affected by the ash composition. The biomass ash composition is in turn essential when it comes to the efficiency of a FBG process. (Badholiya, 2016) Biomass fuels with high ash content and low ash melting temperatures have limited possibilities for successful applications due to problems with ash melting, and agglomeration that occur under certain conditions. (Dragutinovic 2017) In general, woody biomass has very low ash content, typically below $1 \%$, of which approximately $40 \%$ calcium $(\mathrm{Ca}), 15 \%$ potassium $(\mathrm{K})$ and $20 \%$ Si. (Vassilev et al., 2017)

Previous studies have indicated that the bed agglomeration process is heavily dependent on the chemical characteristics and melting behaviors of the coating on the surface of the bed particles (Vassilev et al., 2017). Typically, elements such as $\mathrm{Ca}$ and magnesium $(\mathrm{Mg})$ increase the ash melting temperature, while $\mathrm{Si}, \mathrm{K}$ and sodium (Na) decreases the ash melting temperature. The combination of high $\mathrm{Si}$ and high alkali content is especially problematic for fluidized bed biomass gasification because of the formation of silicates with low melting temperature. (BISYPLAN, 2012)

Apart from the chemical reactions that happens when ash melts and interacts with the fluid dynamics in the bed, the operating temperature is the most important factor determining the time-scale of the agglomeration process in fluidized beds. (Van der Drift, 1999) Good knowledge about the ash melting temperatures is 
therefore of great relevance to avoid operational problems during biomass gasification in fluidized beds. In general terms, ash is used to describe the inorganic matter in fuels. In biomass fuels, the content of the critical inorganic alkali metals tends to vary within the same type of biomass, as well as between the different biomass species. (Badholiya, 2016) This makes it difficult to determine the ash melting behavior on the basis of the melting temperature of the individual components. Another challenge when it comes to determination of the melting behavior for biomass ash, is that it under certain conditions can react to form eutectics with lower melting point than the individual components. (Dragutinovic, 2017) Performing ash melting analyses can be a useful way to estimate the tendency of bed agglomeration. The method for analyzing the ash melting behavior involves heating the ash in a controlled manner and then determining the temperatures at which the ash begins to deform, soften and completely fuse. This method gives a realistic prediction of the initial agglomeration temperature, i.e. the temperature where the first molten phases that are able to glue particles together are visible. (BISYPLAN, 2012)

\section{Material and methods}

\subsection{Ash melting analysis}

The biomass fuel was ashed at $600^{\circ} \mathrm{C}$ using a muffle furnace, and the ash was subsequently analyzed using a Leco Ash Fusion Determinator (AF700). To prepare the biomass ash sample for ash-melting analysis, the ash was milled and wetted with a few drops of Dextrin solution (Part no: 502-010) before it was pressed into a cylindrical test piece (Figure 3) with specified dimensions. The test piece was mounted on a ceramic tray and placed in the high-temperature furnace.

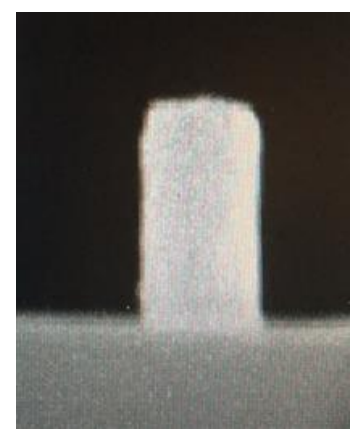

Figure 3. Cylindrical test piece ready for ash melting analysis.

For the ash-melting analyses, the Approved Standard Test Method (ASTM) D1857 was used. This test involves heating of the ash samples at a defined heating rate in reducing conditions. Table 1 shows the ASTM method specifications.
Table 1. Ash melting analyses specifications.

\begin{tabular}{|l|l|l|l|}
\hline Step & 1 & 2 & Unit \\
\hline Start temperature & 400 & 700 & ${ }^{\circ} \mathrm{C}$ \\
\hline End temperature & 700 & 1500 & ${ }^{\circ} \mathrm{C}$ \\
\hline Ramp rate & 20 & 10 & ${ }^{\circ} \mathrm{C} / \mathrm{min}$ \\
\hline Ramp time & $00: 15$ & $01: 20$ & $\mathrm{H}: \mathrm{min}$ \\
\hline Hold time & $00: 00$ & $00: 00$ & H:min \\
\hline Total time & $00: 15$ & $01: 20$ & H:min \\
\hline
\end{tabular}

Four characteristic temperatures were determined for the ash sample: (ST) Shrinking starting Temperature, (DT) Deformation Temperature, (HT) Hemispherical temperature and (FT) Flow Temperature. Each of these temperatures correspond to a specific shape of the cylindrical ash test piece, and are described in Table 2 (BISYPLAN, 2012).

Table 2. Characteristic temperatures in ash melting analyses.

\begin{tabular}{|l|l|}
\hline $\begin{array}{l}\text { Characteristic } \\
\text { temperature }\end{array}$ & Description \\
\hline ST & $\begin{array}{l}\text { First sign of shrinking of the } \\
\text { cylinder }\end{array}$ \\
\hline DT & $\begin{array}{l}\text { First sign of rounding due to } \\
\text { melting of the corners of the } \\
\text { cylinder }\end{array}$ \\
\hline HT & $\begin{array}{l}\text { The cylindrical test piece forms a } \\
\text { hemisphere }\end{array}$ \\
\hline FT & $\begin{array}{l}\text { The cylindrical test piece has } \\
\text { effectively melted and the ash are } \\
\text { spread out over the supporting tile } \\
\text { in a layer }\end{array}$ \\
\hline
\end{tabular}

\subsection{CPFD model description}

The CPFD software package Barracuda VR 17.1.0 was used to simulate the agglomeration process in a biomass bubbling FBG. Barracuda VR uses the Multiphase Particle-in-Cell (MP-PIC) based Eulerian-Lagrangian approach, where the transport equations are solved for the continuous fluid phase and each of the discrete particles are tracked through the calculated fluid field. The fluid-particle interaction is considered as source terms in the transfer of mass, momentum and energy between the two systems. CPFD simulations are hybrid numerical methods, where the Eulerian approach is used for solving the fluid phase and the Lagrangian computational particle approach is used for solving the particle phase (Thapa and Halvorsen, 2013). Chladek et al. (2018) and Jayarathna et al. (2017) have described the transport equations in detail.

The Barracuda software package includes several drag models. For the present simulations, the Wen-Yu drag model was used. The CPFD model are previously developed and validated against experiments performed in a lab-scale cold flow model by Furuvik et al (2018). The model was scaled up to a full-scale bubbling FBG 
reactor using Glicksman's scaling rules that are based on a set of dimensionless parameters. The scaling rules are explained in detail by Thapa et al (2013).

A three-dimensional Cartesian coordinate system was used to describe the cylindrical column with height of $250 \mathrm{~cm}$ and $42 \mathrm{~cm}$ in diameter. In the present study, the static bed height was $105 \mathrm{~cm}$. The mesh size was $0.0466 \mathrm{~m} \times 0.0466 \mathrm{~m} \times 0.0466 \mathrm{~m}$ and the number of control volumes was 4 536. The simulations were carried out at three different temperature conditions: (I) $850{ }^{\circ} \mathrm{C}$, (II) $900{ }^{\circ} \mathrm{C}$ and (III) $1000{ }^{\circ} \mathrm{C}$, and for each temperature, two different agglomeration processes were simulated. The fluidizing gas was air at atmospheric pressure. Pressure transducers are placed with an interval of $10 \mathrm{~cm}$ along the height of the bed, and the first monitor point is $10 \mathrm{~cm}$ above the distributor. The simulations were run for 50 seconds with a time step of $0.001 \mathrm{~s}$. The simulation conditions are summarized in Table 3.

Table 3. CPFD simulation conditions.

\begin{tabular}{|c|c|}
\hline Operating parameter & Value \\
\hline Number of grid cells & 4536 \\
\hline Static bed height & $105 \mathrm{~cm}$ \\
\hline Fluidizing agent & Air \\
\hline Type of flow & $\begin{array}{l}\text { Isothermal@ } \\
\text { (I) } 850^{\circ} \mathrm{C} \\
\text { (II) } 900^{\circ} \mathrm{C} \\
\text { (III) } 1000^{\circ} \mathrm{C}\end{array}$ \\
\hline Superficial air velocity & $0.02 ; 0.005 ; 0.15 \mathrm{~m} / \mathrm{s}$ \\
\hline $\begin{array}{l}\text { Simulation time for each } \\
\text { flowrate }\end{array}$ & $50 \mathrm{~s}$ \\
\hline Drag model & Wen-Yu \\
\hline
\end{tabular}

Quarts sand with a solid density of $2650 \mathrm{~kg} / \mathrm{m}^{3}$ was used as bed material. The particle size of the sand were $300 \mu \mathrm{m}$. The agglomerates ranged from $1.0 \mathrm{~cm}$ to 4.0 $\mathrm{cm}$ in diameter, with a particle density of $1506 \mathrm{~kg} / \mathrm{m}^{3}$. (Furuvik et al., 2018). The maximum close pack volume fraction was set to 0.54 . The maximum momentum from the redirection of particles collision was assumed to be $40 \%$, the normal-to-wall and tangential-to-wall momentum retention were 0.3 and 0.99 respectively. The particle properties are listed in Table 4.

Table 4. Particle properties.

\begin{tabular}{|l|l|l|}
\hline Property & Bed material & Agglomerates \\
\hline Diameter & $300 \mu \mathrm{m}$ & $1.0-4.0 \mathrm{~cm}$ \\
\hline Density & 2650 & 1506 \\
\hline Sphericity & 0.86 & 0.6 \\
\hline $\begin{array}{l}\text { Close pack volume } \\
\text { fraction }\end{array}$ & 0.54 & N/A \\
\hline
\end{tabular}

For the present simulations, it was assumed that the agglomeration process started at the DT measured by the ash melting analyses, and that the size and amount of agglomerates accumulate once the process has been initiated. In total, six different simulation cases were performed. Specific details on the agglomeration processes in the different simulation cases are presented in Table 5.

Table 5. CPFC simulation specification

\begin{tabular}{|l|l|l|l|}
\hline & $850^{\circ} \mathrm{C}$ & $900^{\circ} \mathrm{C}$ & $1000^{\circ} \mathrm{C}$ \\
\hline Amount of & 0 & $20 \%$ & $20 \%$ \\
agglomerates & $15 \%$ & $20 \%$ & $30 \%$ \\
\hline $\begin{array}{l}\text { Size of } \\
\text { agglomerates }\end{array}$ & $-1-2 \mathrm{~cm}$ & $2-3 \mathrm{~cm}$ & $3-4 \mathrm{~cm}$ \\
\hline
\end{tabular}

\section{Results and discussion}

\subsection{Ash melting analysis}

Woodchips from Austria were used for the laboratory prepared ash samples. The ash-processing temperature was $600^{\circ} \mathrm{C}$. In Figure 4, the form of the cylindrical test piece is pictured for each of the defined characteristic temperatures.
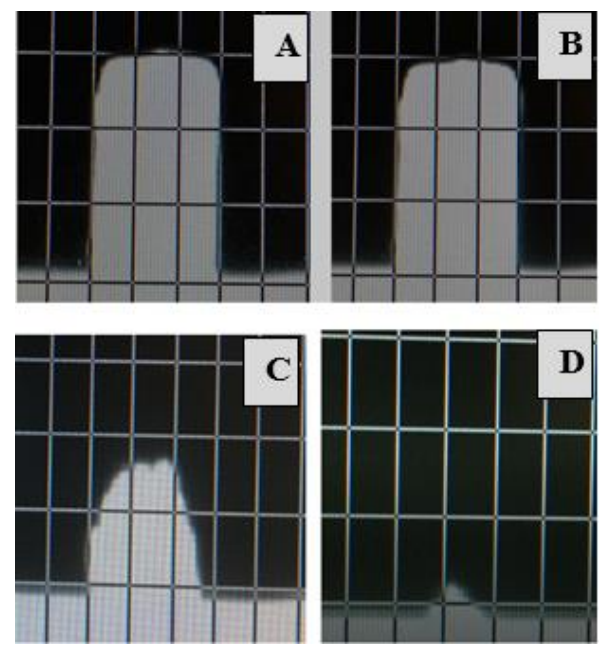

Figure 4. Results from ash melting analyses showing the test piece at (A) ST, (B) DT, (C) HT and (D) FT.

In order to obtain reasonable results, three separate measurements were carried out. The four characteristic temperatures were determined for all the three measurements. The results from the ash melting analyses are listed in Table 6 .

Table 6. Results from ash melting analyses.

\begin{tabular}{|l|l|l|l|l|}
\hline & $S T$ & $D T$ & $H T$ & $F T$ \\
\hline 1 & $861^{\circ} \mathrm{C}$ & $870^{\circ} \mathrm{C}$ & $1466^{\circ} \mathrm{C}$ & $1492^{\circ} \mathrm{C}$ \\
\hline 2 & $867^{\circ} \mathrm{C}$ & $874^{\circ} \mathrm{C}$ & $1472^{\circ} \mathrm{C}$ & $1492^{\circ} \mathrm{C}$ \\
\hline 3 & $859^{\circ} \mathrm{C}$ & $865^{\circ} \mathrm{C}$ & $1463^{\circ} \mathrm{C}$ & $1490^{\circ} \mathrm{C}$ \\
\hline
\end{tabular}

For all the three measurements, the ash started to show sign of shrinking around $860^{\circ} \mathrm{C}$ and deformation and rounding were observed at approximately $870^{\circ} \mathrm{C}$, these are the temperatures that correspond to ST and DT respectively. For biomass fuels, the DT is considered as a valid indication for the tendency of the ash to cause 
problems during thermal conversion processes. (BISYPLAN, 2012) In the present study, the received data for the DT are further related to the initial agglomeration temperatures.

\subsection{CPFD simulations}

The CPFD simulations were carried out at three different temperatures, and with varying combination of size and amount of agglomerates in the bed. The chosen simulation temperatures were based on the measured DT from the ash melting analyses, assuming the initial ash-melting temperature will start the agglomeration process. It was also assumed that the process continues once it has been initiated. The CPFD simulation results are presented as plots of the pressure drop in the bed as a function of the superficial air velocity.

Figure 5 represents the results of the simulations at $850^{\circ} \mathrm{C}$. The red line represents fluidization of the bed material, and is used as a reference bed. The purple line represents $15 \%$ agglomeration in the bed. From the figure it is seen that there is a clear correlation between the fluid dynamics and the bed agglomeration processes. The difference between the pressures drops in the two cases increases with increasing superficial velocity until the bed is fluidized, at about $0.06 \mathrm{~m} / \mathrm{s}$. The pressure drop at minimum fluidization is approximately $14000 \mathrm{~Pa} / \mathrm{m}$ in the reference bed, while it is decreased to approximately $12000 \mathrm{~Pa} / \mathrm{m}$ in the agglomerated bed.

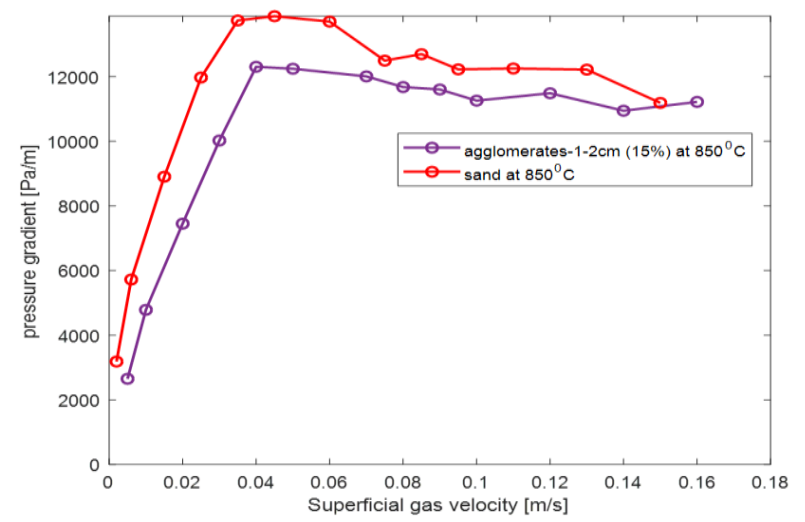

Figure 5. CPFD simulations at $850^{\circ} \mathrm{C}$, (I) silica sand, no agglomeration (II) agglomerate size $1-2 \mathrm{~cm}$ and $15 \%$ agglomeration.

Figure 6 shows the results from the two simulation cases at $900^{\circ} \mathrm{C}$. In both of the cases $20 \%$ agglomerates are present in the bed. The blue line represents the case with agglomerates of 2-3 cm, while the black line represents agglomerates of 3-4 $\mathrm{cm}$. The deviation between the two curves indicates that the fluidization is greatly affected by the size of the agglomerates. When the maximum size of the agglomerates is increased from $3 \mathrm{~cm}$ to $4 \mathrm{~cm}$, the minimum fluidization velocity is increased from about $0.05 \mathrm{~m} / \mathrm{s}$ to $0.08 \mathrm{~m} / \mathrm{s}$. The minimum fluidization velocity is a key parameter in fluidized beds, and works as a rough indication of the quality of the fluidization. Minimum fluidization is the point at which the bed conditions are at the boundary between fixed and fluidized, and the corresponding superficial velocity is referred to as the minimum fluidization velocity. The superficial velocity should therefore always be kept well above the theoretical minimum fluidization velocity to prevent defluidization of the bed

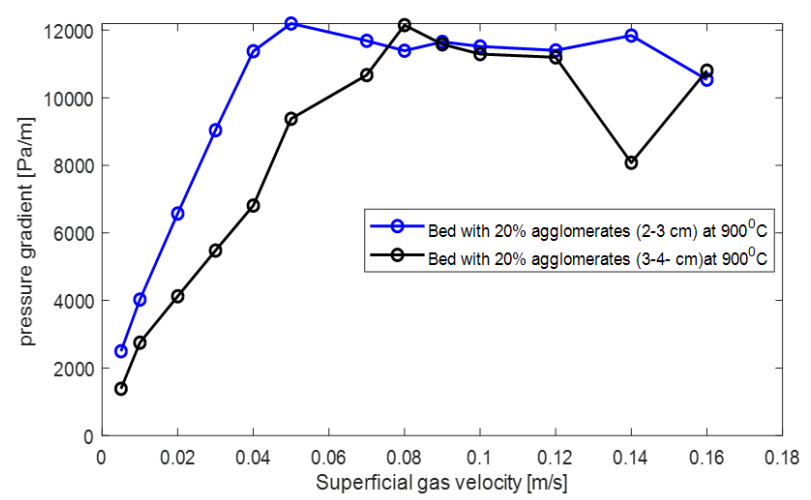

Figure 6. CPFD simulations at $900^{\circ} \mathrm{C}$, (I) agglomerate size $2-3 \mathrm{~cm}$ and $20 \%$ agglomeration (II) agglomerate size $3-4 \mathrm{~cm}$ and $20 \%$ agglomeration.

Figure 7 shows the results from the simulations at $1000^{\circ} \mathrm{C}$. The size of the agglomerates is $3-4 \mathrm{~cm}$ in both the simulation cases. The green line represents the case with $20 \%$ agglomeration and the yellow line is simulation with $30 \%$ agglomeration. The simulation results displayed in Figure 5 indicates that agglomeration causes decreased pressure drop in the fluidized bed. From Figure 7, it is seen that as the agglomerates grow larger it results in heavy instabilities in the bed. The pressure drop across the bed start to fluctuate as soon as the bed achieves fluidized state. The fluctuation in the pressure drops becomes worse as the amount of agglomerates increases. This improper bed control indicates de-fluidization. Apparently around $20 \%$ agglomeration seems to be enough to initiate defluidization of the bed.

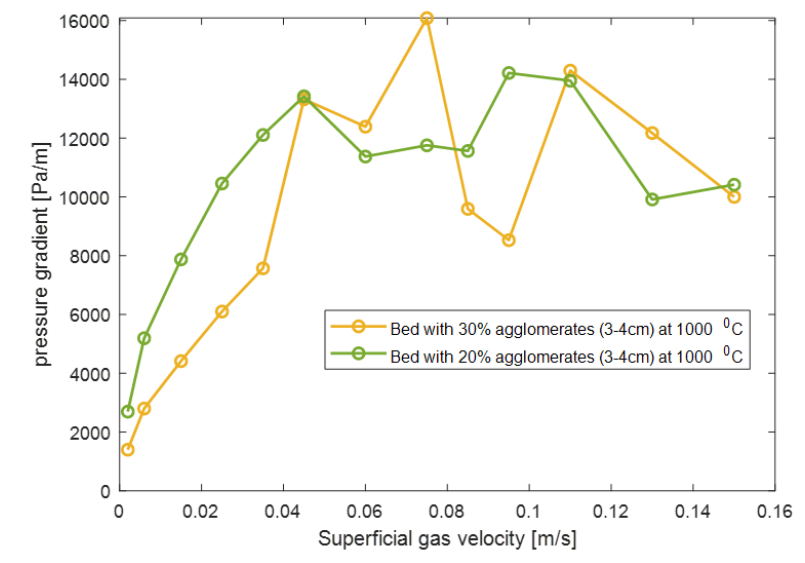

Figure 7. CPFD simulations at $1000^{\circ} \mathrm{C}$, (I) agglomerate size $3-4 \mathrm{~cm}$ and $20 \%$ agglomeration (II) agglomerate size 3-4 $\mathrm{cm}$ and $30 \%$ agglomeration. 


\section{Conclusion}

The objective of this work was to use a previous developed and validated CPFD model to study the ash melting and agglomeration in biomass gasification in a bubbling fluidized bed. The study included ash melting analyses, and CPFD simulations using the commercial software Barracuda VR. Ash related problems are the main obstacle in fluidized bed gasification of biomass, and are generally associated with high content of alkali components in the fuels. These elements might form low-melting temperature compounds that will coat the surface of the bed particles. If the coating have high enough fraction of molten ash, it will cause bed agglomeration.

The measurement of ash melting temperatures provides a direct correlation between laboratory data and the temperature at which the ash might have the tendency to melt. The simulations shows that the agglomeration process will affect the fluid dynamics in a bubbling fluidized bed gasifier. Bed agglomeration is often seen as a consequence of improper bed control. The more and larger agglomerates, the more severe are the problems. The point where agglomeration starts to cause problems is characterized by a sudden drop or instability in pressure. The simulations shows that around $20 \%$ agglomerates seems to be enough to initiate de-fluidization of the fluidized bed.

\section{Acknowledgements}

This study is funded by The Research Council of Norway, Program for Energy Research (ENERGIX), Project 280892 FLASH - Predicting of FLow behavior of ASH mixtures for production of transport biofuels in the circular economy.

\section{References}

A.B. Khadilkar, P.L. Rozelle, and S.V. Pisupati. Investigation of fluidized bed agglomerate growth process using simulations and SEM-EDX characterization of laboratorygenerated agglomerates. Chemical Engineering Science, 184: 172-185, 2018.

A. van der Drift. Conversion of Biomass, prediction and solution methods for ash agglomeration and related problems. Final Report, ECN-C-99.090, 1999.

BISYPLAN. Web-based handbook, 2012. Available from: http://bisyplan.bioenarea.eu/ash_appendix.html. 02.06.2019.

C.K. Jayarathna, B.M.E. Moldestad, and L.A. Tokheim. Validation of results from Barracuda ${ }^{\circledR}$ CFD modelling to predict minimum fluidization velocity and pressure drop of Geldart A particles. Proceedings for the $58^{\text {th }}$ SIMS conference, 2017.

J. Chladek, C.K. Jayarathna, B.M.E. Moldestad, and L.A. Tokheim. Fluidized bed classification of particles of different sixe and density. Chemical Engineering Science, 177: 155-162, 2018.
L. Wang, C.L. Weller, D.D., and M.A. Hanna. Contemporary issues in thermal gasification of biomass and its application to electricity and fuel production. Biomass and Bioenergy, 32: 573-581, 2008.

M. Bartles, W. Lin, J. Nijenhuis, F. Kapteijn and R. Ommen. Agglomeration in fluidized beds at high temperatures: Mechanisms, detection and prevention. Progress in Energy and Combustion Science, 34: 633-666, 2008.

N. Dragutinovic, B. Nakomcic-Smaragdakis, and Z. Cepic. Comparison of ash melting behavior of crop residues and woody biofuels with recommended measures. The 8th PSUUNS International Conference on Engineering and Technology (ICET-2017), Novi Saf, Serbia, June 8-10, 2017.

N.C.I.S. Furuvik, R. Jaiswal, and B.M.E. Moldestad. Flow behavior in an agglomerated fluidized bed gasifier. International Journal for Energy and Environment, 10(2): 55-64, 2019.

N.C.I.S. Furuvik, R. Jaiswal, R.K. Thapa, and B.M.E. Moldestad. CPFD model for prediction of flow behavior in an agglomerated fluidized bed gasifier. International Journal for Energy Production and Management, 4(2):105114, 2019.

P. Basu. Biomass Gasificaion, Prolysis and Torrefaction, Second Edition. Academic Press Inc., UK, 2013.

R.K. Thapa and B.M. Halvorsen. Study of Flow Behavior in Bubbling Fluidized Bed Biomass Gasification Reactor using CFD simulation. The 14th International Conference on Fluidization - From Fundamentals to Products, Eds, ECI Symposium Series, 2013.

R.K. Thapa, C. Pfeifer, and B.M. Halvorsen. Scaling of biomass gasification reactor using CFD simulations. In International conference on Polygeneration strategies (IPCS), Vienna, Austria, June 3-5, 2013.

S.K. Badholiya and A. Kothari. A review on ash agglomeration phenomenon in fluidized bed combustion boiler. International Journal of Scientific Research Engineering \& Technology (IJSRET), 5(11): 533-541, 2016

S.K Badholiya, S.K. Pradhan and A. Kothari. Investigations on ash agglomeration in CFBC boiler using computational fluid dynamics. International Journal of Mechanical Engineering and Technology (IJMET), 9(7): 1464-1476, 2018.

S.V. Vassilev, C.G. Vassilev, Y. Song, W. Li and J. Feng. Ash contents and ash-forming elements of biomass and their significance for solid biofuel combustion. Fuel, 208: 377409, 2017.

S. Visser, S. van Lith and J. Kiel J. Biomass Ash - Bed Material Interactions Leading to Agglomeration in FBC. Journal of Energy Resources Technology, 2008.

World Bioenergy Association. WBA Global Bioenergy Statistics, 2017. 